\title{
Carcass and meat quality of primiparous sows as related to the lactation period of 21 or 28 days and to body weight loss
}

\author{
Jolanta Kapelanska, Salomea Grajewska, Maria Bocian, Hanna Jankowiak, \\ Wojciech Kapelanski
}

University of Technology and Life Sciences in Bydgoszcz, Faculty of Animal Breeding and Biology, Department of Pig Breeding, Poland

Received October 6, 2011

Accepted May 16, 2012

\begin{abstract}
The study included 70 primiparous sows nursing piglets for 21 days and 30 sows nursing piglets for 28 days. Body weight of the sows was recorded at mating, farrowing, weaning and slaughter. The assessment covered the degree of sow body weight loss and its influence on carcass and meat quality as related to the lactation period and to the extent of lactation body loss below $5 \%$, from 5 to $10 \%$ and over $10 \%$ of body weight. Carcass quality as well as physicochemical meat traits were also subjected to evaluation. Extending the nursing period from 21 to 28 days increased the average lactation body weight loss from 7.88 to $8.50 \%(P \leq 0.01)$. This did not influence the carcass quality in any noticeable way; nonetheless, some meat traits did yield less favourable results. These were related to the electric conductivity of the meat as well as its water holding capacity and colour $(P \leq 0.01)$. The same undesirable tendency was observed in the group of sows with body weight losses exceeding $10 \%$. It resulted in the decrease of backfat thickness $(P \leq 0.01)$ and reduction of certain meat traits, particularly lower protein content $(P \leq 0.05)$. Lower carcass fatness of primiparous sows is a beneficial trait in preparation of a heavy pig for slaughter.
\end{abstract}

Once-bred sows, slaughter performance, lactation period

A slaughter use of once-bred sows after rearing the first litter offers an alternative and profitable pork production system (Kapelanski et al. 2010). Regardless of similar carcass weight, in comparison to heavy fatteners such sows exhibit low fatness and thin backfat (Kapelanski and Grajewska 2005). Furthermore, the slaughter value of such animals is improved by their high meat quality (Kapelanski et al. 2007a,b).

The lactation period in sows is connected with a high loss of energy and nutrients required for the milk production that exceeds the capability of taking energy up from the fodder. This leads to body weight losses, mainly fat reserves, but also to the loss of protein, water and other nutrients (Revell et al. 1998; Jones and Stahly 1999; Kim and Easter 2001; Thaker and Bilkei 2005).

Even with a standardized size of litters and a uniform feeding programme the degree of body weight loss during lactation demonstrates considerable variability. It has been proven that during lactation, the sows differ in the size of metabolic rate and metabolic adjustment (Valros et al. 2003). The length of lactation period influences the extent of sow body weight loss as well. A 21 day lactation period in gilts assigned to slaughter after weaning their first litter was recommended earlier (Kapelanski and Grajewska 2005). However, in accordance with the Council Directive 2001/93/EC, piglet age at weaning should be increased from 21 to 28 days (Colson et al. 2006).

Extending the lactation period may therefore result in excessive body weight and muscle protein losses that might adversely affect the carcass and meat quality traits of the sows. The aim of this study was to compare the changes in carcass and meat quality in primiparous sows following a 21 and 28 day lactation period.

Address for correspondence:

Dr. Jolanta Kapelańska

Department of Pig Breeding

University of Technology and Life Sciences in Bydgoszcz

Mazowiecka 28 Street, 85-084 Bydgoszcz, Poland 


\section{Materials and Methods}

The study was carried out using 100 primiparous Polish Large White $\times$ Polish Landrace $(\mathrm{PLW} \times \mathrm{PL})$ crossbreed sows. Management and housing were the same as for replacement gilts. Animal feeding was in accordance with the Feeding Standards for Pigs (1993). The experimental procedures were approved by the Local Ethics Committee.

The age and weight of primiparous sows were recorded at mating, farrowing and weaning; litter size and litter weight were recorded at birth and at weaning. One group of sows $(n=70)$ nursed piglets for 21 days, the other one $(\mathrm{n}=30)$ nursed piglets for 28 days. The animals intended to be nursing for 28 days were mated at second natural oestrus. Individual body weight loss of sows during the lactation period was recorded. Moreover, irrespective of the suckling period, all sows were divided into three groups with respect to the range of body weight loss, i.e. up to $5 \%$ (Group 1), from 5\% to $10 \%$ (Group 2), and above 10\% (Group 3) body weight at farrowing. In order to determine the effect of the number of suckling piglets, the sow's lactation body weight loss per one weaned piglet was calculated.

About 10 days after weaning, the sows were slaughtered in accordance with the relevant standards. Carcass slaughter traits were recorded such as warm carcass weight, hot dressing percentage, mean backfat thickness from five measurements: over the shoulder, on the back, on the cranial edge (sacrum I), on the middle (sacrum II) and on the caudal edge (sacrum III) of $\mathrm{m}$. gluteus medius, and on the loin eye area at last thoracic and first lumbar vertebrae.. Carcass lean content was estimated by the use of Ultra FOM 300 device (Ultra sound Fat-o-Meater) adopted in UE to pork carcass classification system.

Meat quality traits were determined on Longissimus lumborum muscle (LL). Measurements of muscle acidity at 45 min post mortem $\left(\mathrm{pH}_{1}\right)$ were made with a portable pistol $\mathrm{pH}$-meter ( $\mathrm{R}$. Mathaus, Germany). At the same time, meat electrical conductivity $\left(\mathrm{EC}_{1}\right)$ was measured using the LF-STAR apparatus (R. Mathaus, Germany). Further analyses were done on a LL sample $48 \mathrm{~h}$ post mortem. The ultimate $\mathrm{pH}\left(\mathrm{pH}_{\mathrm{u}}\right)$ was determined in minced and water-suspended meat. Water holding capacity (WHC) was analysed using the filter paper press method (Grau and Hamm 1952) as modified by Pohja and Niinivaara (1957) and was expressed as the percentage of loose water in meat. $L$ value of meat colour was measured using photocolorimeter MINOLTA CR 310. Water, crude protein, intramuscular fat and ash content were determined according to AOAC procedures (AOAC 2003).

The results obtained were processed statistically computing the arithmetic means for every trait (x) and standard deviations (s). Two-way variance analysis ANOVA/MANOVA was performed for the lactation period and the lactational body weight loss. Covariance analysis ANCOVA including the sow's age and body weight at mating as assisted variants was also computed. The significance of differences between groups 1, 2 and 3 were defined post hoc using Duncan test, and those between the 21 and 28 day lactation periods was assessed using Student's $t$-test. Calculations were performed with the computer program STATISTICA software (StatSoft, Inc. 2008).

\section{Results}

The results relating to the effect of the 21 and 28 day lactations on the body weight loss in sows and to the range of lactational weight loss in the three groups (group 1: $<5 \%$; group 2: 5-10\%; group 3: > 10\%) are presented in Table 1 .

Longer lactation period resulted in an increase in the body weight loss from 12.64 to $15.22 \mathrm{~kg}$, which amounted to $7.88 \%$ and $8.50 \%$, respectively, of the body weight loss of sows. The highest body weight loss occurred in sows of group $3(13.03 \%$ and $14.86 \%)$. Inverse relation was noted in group 1, where greater body weight loss occurred in the 21 day lactation period $(P \leq 0.05)$.

The number of piglets farrowed, nursed and weaned in the sows subject to 21 days lactation was lower than the number obtained with the 28-day suckling period (9.16 and 9.52 respectively; $P \leq 0.05)$. The lactation body weight loss in sows during the 21 - and 28 -day nursing period calculated per one reared piglet were on average similar $(1.35 \mathrm{~kg}$ at $21^{\text {st }}$ day and $1.56 \mathrm{~kg}$ at $28^{\text {th }}$ day) but were highly different in particular sow body loss groups (from 0.60 and $0.44 \mathrm{~kg}$ in group 1 to 2.21 and $2.63 \mathrm{~kg}$ in group 3, respectively). The body weight of sows at weaning in both lactation periods was considerably diverse and on average amounted to $148.30 \mathrm{~kg}$ for the sows nursing for 21 days compared to $161.94 \mathrm{~kg}$ in the sows with a 28-day nursing period $(P \leq 0.01)$.

Means and standard deviations for body weight changes of primiparous sows as related to the lactation period and lactational loss of body weight are presented in Table 2. Only in group 1 of sows with minimal body weight loss during lactation, the weight of a warm carcass similarly as the body weight at slaughter were significantly higher in sows nursing for 28 days $(P \leq 0.01)$. A higher dressing percentage was found in sows with higher carcass 
Table 1. Means (x) and standard deviations (sd) for body weight changes of primiparous sows as related to the lactation period and lactational loss body weight.

\begin{tabular}{|c|c|c|c|c|c|}
\hline \multirow{3}{*}{ Trait } & \multirow{3}{*}{$\begin{array}{l}\text { Lactation } \\
\text { period (days) }\end{array}$} & \multicolumn{4}{|c|}{ Lactational loss } \\
\hline & & Group 1 & Group 2 & Group 3 & Total \\
\hline & & $<5 \%$ & $5 \%-10 \%$ & $>10 \%$ & \\
\hline \multirow[t]{2}{*}{ Number (n) } & 21 & 17 & 43 & 10 & 70 \\
\hline & 28 & 6 & 5 & 19 & 30 \\
\hline \multirow{2}{*}{$\begin{array}{l}\text { Age of gilts at } \\
\text { mating (days) }\end{array}$} & 21 & $198.76^{\mathrm{D}} \pm 3.68$ & $195.09^{\mathrm{D}} \pm 2.31$ & $206.40 \pm 4.80$ & $200.08^{x} \pm 2.16$ \\
\hline & 28 & $218.17^{\mathrm{E}} \pm 6.19$ & $227.60^{\mathrm{E}} \pm 6.78$ & $219.21 \pm 3.48$ & $221.66^{\mathrm{Y}} \pm 3.27$ \\
\hline \multirow{2}{*}{$\begin{array}{l}\text { Body weight at } \\
\text { mating }(\mathrm{kg})\end{array}$} & 21 & $105.47^{\mathrm{D}} \pm 1.98$ & $105.75^{\mathrm{D}} \pm 1.24$ & $107.05^{\mathrm{D}} \pm 2.58$ & $106.09^{x} \pm 1.16$ \\
\hline & 28 & $125.00^{\mathrm{E}} \pm 3.33$ & $127.40^{\mathrm{E}} \pm 3.65$ & $122.95^{\mathrm{E}} \pm 1.87$ & $125.11^{\mathrm{Y}} \pm 1.76$ \\
\hline \multirow{2}{*}{$\begin{array}{l}\text { Body weight } \\
\quad \text { before parturition }(\mathrm{kg})\end{array}$} & 21 & $173.12^{\mathrm{d}} \pm 4.10$ & $178.81^{\mathrm{d}} \pm 2.58$ & $183.80^{\mathrm{D}} \pm 5.34$ & $178.58^{x} \pm 2.40$ \\
\hline & 28 & $193.17^{\mathrm{e}} \pm 6.90$ & $197.80^{\mathrm{e}} \pm 7.56$ & $207.89^{\mathrm{E}} \pm 3.87$ & $199.62^{Y} \pm 3.65$ \\
\hline \multirow{2}{*}{$\begin{array}{l}\text { Body weight } \\
\text { after parturition }(\mathrm{kg})\end{array}$} & 21 & $156.97^{\mathrm{d}} \pm 3.84$ & $160.65 \pm 2.42$ & $165.20^{\mathrm{D}} \pm 5.01$ & $160.94^{x} \pm 2.25$ \\
\hline & 28 & $175.83^{\mathrm{e}} \pm 6.47$ & $174.40 \pm 7.09$ & $180.84^{\mathrm{E}} \pm 3.63$ & $177.02^{\mathrm{Y}} \pm 3.42$ \\
\hline \multirow{2}{*}{$\begin{array}{l}\text { Body weight } \\
\text { after weaning }(\mathrm{kg})\end{array}$} & 21 & $152.06^{\mathrm{D}} \pm 3.61$ & $149.34 \pm 2.27$ & $143.50 \pm 4.71$ & $148.30^{\mathrm{x}} \pm 2.12$ \\
\hline & 28 & $171.67^{\mathrm{aE}} \pm 6.08$ & $159.80 \pm 6.66$ & $154.37^{\mathrm{b}} \pm 3.41$ & $161.94^{\mathrm{Y}} \pm 3.21$ \\
\hline \multirow{2}{*}{$\begin{array}{l}\text { Lactational loss } \\
\text { of body weight }(\mathrm{kg})\end{array}$} & 21 & $4.91^{\mathrm{A}} \pm 0.99$ & $11.31^{\mathrm{B}} \pm 0.62$ & $21.70^{\mathrm{CD}} \pm 1.29$ & $12.64^{\mathrm{x}} \pm 0.58$ \\
\hline & 28 & $4.17^{\mathrm{A}} \pm 1.67$ & $14.60^{\mathrm{B}} \pm 1.83$ & $26.89^{\mathrm{CE}} \pm 0.94$ & $15.22^{Y} \pm 0.88$ \\
\hline \multirow{3}{*}{$\begin{array}{l}\text { Lactational loss } \\
\text { of body weight } \\
(\%)\end{array}$} & 21 & $3.53^{\mathrm{A}} \pm 0.49$ & $7.08^{\mathrm{B}} \pm 0.31$ & $13.03^{\mathrm{Cd}} \pm 0.64$ & $7.88^{x} \pm 0.29$ \\
\hline & & $*$ & & & \\
\hline & 28 & $2.29^{\mathrm{A}} \pm 0.83$ & $8.35^{\mathrm{B}} \pm 0.91$ & $14.86^{\mathrm{Ce}} \pm 0.47$ & $8.50^{Y} \pm 0.44$ \\
\hline \multirow{2}{*}{$\begin{array}{l}\text { Number of } \\
\text { weaned piglets (n) }\end{array}$} & 21 & $8.35 \pm 0.38$ & $9.23 \pm 0.24$ & $9.90 \pm 0.49$ & $9.16^{x} \pm 0.22$ \\
\hline & 28 & $8.50^{\mathrm{a}} \pm 0.64$ & $9.60 \pm 0.70$ & $10.47^{\mathrm{b}} \pm 0.36$ & $9.52^{y} \pm 0.34$ \\
\hline \multirow{3}{*}{$\begin{array}{l}\text { Lactational body } \\
\text { loss per } 1 \mathrm{~kg} \\
\text { of weaned litter }(\mathrm{kg})\end{array}$} & 21 & $0.10^{\mathrm{A}} \pm 0.02$ & $0.21^{\mathrm{B}} \pm 0.01$ & $0.39^{\mathrm{C}} \pm 0.04$ & $0.21^{\mathrm{x}} \pm 0.01$ \\
\hline & & & & & \\
\hline & 28 & $0.07^{\mathrm{A}} \pm 0.04$ & $0.26^{\mathrm{B}} \pm 0.02$ & $0.44^{\mathrm{C}} \pm 0.03$ & $0.34^{\mathrm{Y}} \pm 0.03$ \\
\hline \multirow{2}{*}{$\begin{array}{l}\text { Lactational body } \\
\text { loss per one piglet }(\mathrm{kg})\end{array}$} & 21 & $0.60^{\mathrm{A}} \pm 0.12$ & $1.25^{\mathrm{B}} \pm 0.07$ & $2.21^{\mathrm{C}} \pm 0.16$ & $1.35^{\mathrm{x}} \pm 0.07$ \\
\hline & ) 28 & $0.44^{\mathrm{A}} \pm 0.20$ & $1.60^{\mathrm{B}} \pm 0.22$ & $2.63^{\mathrm{C}} \pm 0.11$ & $1.56^{\mathrm{Y}} \pm 0.11$ \\
\hline \multirow{2}{*}{$\begin{array}{l}\text { Body weight at } \\
\text { slaughter }(\mathrm{kg})\end{array}$} & 21 & $156.88^{d} \pm 3.60$ & $152.32 \pm 2.26$ & $147.55 \pm 4.69$ & $152.25 \pm 2.11$ \\
\hline & 28 & $170.33^{\mathrm{Aae}} \pm 6.06$ & $155.60^{\mathrm{b}} \pm 6.64$ & $149.16^{\mathrm{B}} \pm 3.41$ & $158.36 \pm 3.20$ \\
\hline
\end{tabular}

a,b $P \leq 0.05$; ${ }^{\mathrm{A}, \mathrm{B}, \mathrm{C}} P \leq 0.01$ - means in the same row with different letters are significantly different

d,e $P \leq 0.05$; ${ }^{\mathrm{D}, \mathrm{E}} P \leq 0.01$ - means in the same column with different letters are significantly different

${ }^{\mathrm{x}, \mathrm{y}} P \leq 0.05 ;{ }^{\mathrm{X}, \mathrm{Y}} P \leq 0.01-$ means in the same column with different letters for total are significantly different

* Interaction $P \leq 0.05$

weight $(P \leq 0.01)$. The most pronounced differences were observed in backfat thickness in the 28 -day suckling period between the sows which lost below $5 \%$ and above $10 \%$ of body weight (26.70 vs $17.40 \mathrm{~mm}$, respectively, $P \leq 0.01)$. The diminishing of the loin eye area was also noted between those sow groups $(P \leq 0.05)$.

The meat of sows with longer suckling periods (Table 3 ) demonstrated a higher ultimate acidity $\left(\mathrm{pH}_{\mathrm{u}}\right)$, higher electric conductivity $\left(\mathrm{EC}_{1}\right)$, lighter colour with a higher $\mathrm{b}$-value and lower water holding capacity, i.e. more loose water $(P \leq 0.01)$. Chemical analysis of the meat from those sows revealed higher water content and lower total protein content $(P \leq 0.01)$. Intramuscular fat content was not changed either by the lactation period or by lactational loss of body weight in the compared sow groups.

\section{Discussion}

The lactation-induced decrease in fatness related to loss of body weight in sows after rearing the first litter is a favourable phenomenon with regard to the carcass and meat 
Table 2. Means (x) and standard deviations (sd) for carcass traits in primiparous sows as related to the lactation period and lactational loss of body weight.

\begin{tabular}{|c|c|c|c|c|c|}
\hline \multirow[b]{2}{*}{ Trait } & \multirow{2}{*}{$\begin{array}{l}\text { Lactation } \\
\text { period (days) }\end{array}$} & \multicolumn{4}{|c|}{ Lactational loss } \\
\hline & & $\begin{array}{c}\text { Group } 1 \\
<5 \%\end{array}$ & $\begin{array}{c}\text { Group } 2 \\
5 \%-10 \%\end{array}$ & $\begin{array}{c}\text { Group } 3 \\
>10 \%\end{array}$ & Total \\
\hline Hot carcass & 21 & $123.34^{\mathrm{D}} \pm 3.09$ & $119.38 \pm 1.95$ & $115.18 \pm 4.03$ & $119.29^{\mathrm{x}} \pm 1.81$ \\
\hline weight (kg) & 28 & $144.92^{\mathrm{AE}} \pm 5.21$ & $126.62^{\mathrm{B}} \pm 5.71$ & $119.4^{\mathrm{B}} \pm 2.93$ & $130.32^{\mathrm{y}} \pm 2.75$ \\
\hline Dressing & 21 & $78.63^{d} \pm 0.51$ & $78.67^{d} \pm 0,32$ & $78.00 \pm 0.67$ & $78.44^{x} \pm 0.30$ \\
\hline percentage (\%) & 28 & $81.10^{\mathrm{e}} \pm 0.87$ & $80.79^{e} \pm 0.95$ & $79.99 \pm 0.49$ & $80.62^{\mathrm{Y}} \pm 0.46$ \\
\hline Backfat & 21 & $22.80 \pm 0.13$ & $22.10 \pm 0.08$ & $20.00 \pm 0.17$ & $21.60 \pm 0.08$ \\
\hline thickness (mm) & 28 & $26.70^{A} \pm 0.23$ & $22.20 \pm 0.25$ & $17.40^{\mathrm{B}} \pm 0.13$ & $22.10 \pm 0.12$ \\
\hline Loin eye area & 21 & $53.36 \pm 2.11$ & $54.06 \pm 1.33$ & $55.64 \pm 2.75$ & $54.35 \pm 1.24$ \\
\hline$\left(\mathrm{cm}^{2}\right)$ & 28 & $61.88^{\mathrm{a}} \pm 3.55$ & $57.12 \pm 3.89$ & $52.25^{\mathrm{b}} \pm 2.00$ & $57.08 \pm 1.88$ \\
\hline Carcass lean & 21 & $52.13 \pm 1.27$ & $51.63 \pm 0.80$ & $53.82 \pm 1.66$ & $52.53 \pm 0.74$ \\
\hline content $(\%)$ & 28 & $49.57 \pm 2.14$ & $53.74 \pm 2.34$ & $54.45 \pm 1.20$ & $52.59 \pm 1.13$ \\
\hline
\end{tabular}

a,b $P \leq 0.05$; A,B $P \leq 0.01$ - means in the same row with different letters are significantly different

d,e $P \leq 0.05$; ${ }^{\mathrm{D}, \mathrm{E}} P \leq 0.01$ - means in the same column with different letters are significantly different

${ }^{\mathrm{x}, \mathrm{y}} P \leq 0.05 ;{ }^{\mathrm{X}, \mathrm{Y}} P \leq 0.01$ - means in the same column with different letters for total are significantly different

Table 3. Means (x) and standard deviations (sd) for physicochemical meat properties and chemical meat composition of sows as related to the lactation period and lactational loss of body weight.

\begin{tabular}{|c|c|c|c|c|c|}
\hline \multirow{3}{*}{ Trait } & \multirow{3}{*}{$\begin{array}{l}\text { Lactation } \\
\text { period (days) }\end{array}$} & \multicolumn{4}{|c|}{ Lactational loss } \\
\hline & & Group 1 & Group 2 & Group 3 & Total \\
\hline & & $<5 \%$ & $5 \%-10 \%$ & $>10 \%$ & \\
\hline \multirow[t]{2}{*}{$\mathrm{pH}_{1}$} & 21 & $6.45 \pm 0.06$ & $6.37 \pm 0.04$ & $6.37 \pm 0.08$ & $6.39 \pm 0.04$ \\
\hline & 28 & $6.43 \pm 0.11$ & $6.46 \pm 0.12$ & $6.46 \pm 0.06$ & $6.45 \pm 0.06$ \\
\hline \multirow{2}{*}{$\mathrm{pH}_{\mathrm{u}}$} & 21 & $5.49 \pm 0.02$ & $5.49^{\mathrm{d}} \pm 0.01$ & $5.43^{\mathrm{d}} \pm 0.02$ & $5.47^{x} \pm 0.01$ \\
\hline & 28 & $5.54 \pm 0.03$ & $5.55^{\mathrm{e}} \pm 0.03$ & $5.51^{\mathrm{e}} \pm 0.01$ & $5.53^{\mathrm{Y}} \pm 0.01$ \\
\hline \multirow[t]{2}{*}{$\mathrm{EC}_{1}(\mathrm{mS} / \mathrm{cm})$} & 21 & $3.42 \pm 0.20$ & $2.86 \pm 0.13$ & $3.16 \pm 0.27$ & $3.15^{x} \pm 0.12$ \\
\hline & 28 & $3.56 \pm 0.34$ & $3.69 \pm 0.38$ & $3.56 \pm 0.19$ & $3.60^{\mathrm{Y}} \pm 0.18$ \\
\hline \multirow[t]{2}{*}{$L^{*}$} & 21 & $48.83^{\mathrm{D}} \pm 0.54$ & $50.11^{\mathrm{d}} \pm 0.34$ & $50.90^{\mathrm{d}} \pm 0.70$ & $49.90^{x} \pm 0.32$ \\
\hline & 28 & $52.60^{\mathrm{E}} \pm 0.91$ & $52.25^{\mathrm{e}} \pm 0.99$ & $53.60^{\mathrm{e}} \pm 0.51$ & $52.78^{\mathrm{Y}} \pm 0.48$ \\
\hline \multirow[t]{2}{*}{$a^{*}$} & 21 & $15.24^{\mathrm{D}} \pm 0.23$ & $14.99^{\mathrm{D}} \pm 0.15$ & $15.02^{\mathrm{D}} \pm 0.30$ & $15.08^{x} \pm 0.14$ \\
\hline & 28 & $17.56^{\mathrm{AE}} \pm 0.39$ & $16.42^{\mathrm{BE}} \pm 0.43$ & $16.27^{\mathrm{BE}} \pm 0.22$ & $16.75^{\mathrm{Y}} \pm 0.21$ \\
\hline \multirow[t]{2}{*}{$b^{*}$} & 21 & $2.26^{\mathrm{D}} \pm 0.26$ & $2.48^{\mathrm{d}} \pm 0.16$ & $2.44^{\mathrm{D}} \pm 0.33$ & $2.39^{x} \pm 0.15$ \\
\hline & 28 & $5.11^{\mathrm{AE}} \pm 0.43$ & $3.73^{\mathrm{Be}} \pm 0.47$ & $5.27^{\mathrm{AE}} \pm 0.24$ & $4.70^{\mathrm{Y}} \pm 0.23$ \\
\hline WHC, & 21 & $21.40 \pm 0.63$ & $21.45 \pm 0.39$ & $22.05 \pm 0.83$ & $21.63^{\mathrm{x}} \pm 0.37$ \\
\hline loose water $(\%)$ & 28 & $23.07 \pm 1.06$ & $23.26 \pm 1.16$ & $24.44 \pm 0.59$ & $23.59^{\mathrm{Y}} \pm 0.56$ \\
\hline Water content & 21 & $75.29 \pm 0.17$ & $75.70 \pm 0.10$ & $75.51 \pm 0.22$ & $75.50^{\mathrm{x}} \pm 0.10$ \\
\hline$(\%)$ & 28 & $75.57 \pm 0.35$ & $76.29 \pm 0.40$ & $76.15 \pm 0.17$ & $76.00^{\mathrm{Y}} \pm 0.19$ \\
\hline Total protein & 21 & $21.55 \pm 0.21$ & $21.02 \pm 0.13$ & $21.51^{\mathrm{d}} \pm 0.27$ & $21.36^{x} \pm 0.12$ \\
\hline$(\%)$ & 28 & $21.35 \pm 0.43$ & $20.50 \pm 0.50$ & $20.43^{e} \pm 0.21$ & $20.76^{\mathrm{Y}} \pm 0.23$ \\
\hline Intramuscular & 21 & $1.65 \pm 0.11$ & $1.61 \pm 0.07$ & $1.39 \pm 0.14$ & $1.55^{\mathrm{x}} \pm 0.06$ \\
\hline fat $(\%)$ & 28 & $1.91 \pm 0.23$ & $2.02 \pm 0.26$ & $1.84 \pm 0.11$ & $1.92^{y} \pm 0.12$ \\
\hline
\end{tabular}

a,b $P \leq 0.05 ; \mathrm{A}, \mathrm{B} P \leq 0.01$ - means in the same row with different letters are significantly different

d,e $P \leq 0.05$; D,E $^{\mathrm{E}} P \leq 0.01$ - means in the same column with different letters are significantly different

${ }^{\mathrm{x}, \mathrm{y}} P \leq 0.05 ;{ }^{\mathrm{X}, \mathrm{Y}} P \leq 0.01$ - means in the same column with different letters for total are significantly different 
properties. Sows after weaning their first litter provided a much more valuable slaughter material than heavy fatteners; while maintaining high meatiness they were not overly fat (Kapelańska et al. 2002; Kapelanski and Grajewska 2005). However, excessive expenditure of energy and protein for the production of milk might cross the optimally favourable limits and result in lowering the carcass and meat properties by decreasing the consumptive and processing value of the meat. Few early studies led to the assumption that excessive lactation body weight losses in certain sows have an adverse effect on certain meat properties, such as colour, intramuscular fat content as well as tenderness and juiciness of the meat (Kapelanski et al. 2007b).

To a large extent, factors contributing to considerable body weight losses during lactation may relate to inappropriate nutrition (Clowes et al. 2003), long lactation period or exceptionally large litters (Jones and Stahly 1999; Kim and Easter 2001). Our results show significant but not big differences in body weight losses in sows subjected to 21 - and 28-day lactation periods. Body weight loss of sows calculated per one weaned piglet with a longer suckling period was slightly higher; however, in both periods this value proved highly variable and crossed over three times the lactational body weight loss between the first and third sow groups. This indicates changeable capacity of the sow's body to mobilize its components as related to nursing piglets. Some authors believe that there is considerable variability in the status of metabolic processes represented in the varied tendency towards body weight loss during lactation (Revell et al. 1998; Valros et al. 2003).

It is reasonable to assume that considerable lactation losses representing excessive body fat and protein loss have an adverse affect on some reproductive functions in breeding sows (Thaker and Bilkei 2005) and may be the reason for the deterioration of certain meat properties in slaughtered sows. Detailed analysis of the results obtained from this study, taking into account the three body weight loss ranges showed certain similarities between the largest body weight loss and the reduction in certain consumptive qualities of the meat.

Our results confirmed that only sows nursing their piglets for 28 days or demonstrating a loss of over $10 \%$ body weight may be affected by reduction in muscle tissue protein and deterioration of certain consumptive qualities of the meat. The reasons for developing the increased mobilization of body components during lactation are connected with considerable oscillations between individual specimens in terms of both metabolic and hormonal balance of the organism (Revell et al. 1998; Valros et al. 2003). This is also confirmed by data obtained in this study with regard to significantly diversified energy expenditure per nursing one piglet or per $1 \mathrm{~kg}$ of weaned litter.

In conclusion, it seems essential to point out that the longer period results in a larger body weight loss in sows. It has been proven that a deterioration of certain meat properties might occur with a loss of over $10 \%$ of the body weight. Such deterioration relates to a less favourable meat colour and water holding capacity, as well as a decrease in protein content.

\section{Acknowledgements}

Supported by the State Committee for Scientific Research, Grant No PB 2 P06Z 00126.

\section{References}

AOAC 2003: Official Methods of Analysis. 17 $7^{\text {th }}$ Ed., Revision 2, Association of Official Analytical Chemists. AOAC international, Gaithersburg, USA

Clowes EJ, Aherne FX, Foxcroft GR, Baracos VE 2003: Selective protein loss in lactating sows is associated with reduced litter growth and ovarian function. J Anim Sci 81: 753-764

Colson V, Orgeur P, Foury A, Morméde P 2006: Consequences of weaning piglets at 21 and 28 days on growth, behaviour and hormonal responses. Appl Anim Behav Sci 89: 70-88

Council Directive 2001/93/EC aimed to introduce improved standard concerning minimum weaning age of four weeks. Available at www.ec.europa.eu/food/animal/welfare/farm/pigs_en.htm

Grau R, Hamm R 1952: Simple methods of meat water holding capacity determination (in German) Fleischwirtschaft 4: 295-297 
Jones D.B., Stahly T.S. 1999: Impact of amino acid nutrition during lactation on body nutrient mobilization and milk nutrient output in primiparous sows. J Anim Sci 77: 1513-1522

Kapelanska J, Dylas R, Kapelanski W, Dybala J, Rak B, Grajewska S 2002: Slaughter value and meat quality of primiparous gilts. Ann Anim Sci (Suppl) 2: 297-300

Kapelanski W, Bocian M, Kapelanska J, Grajewska S, Jankowiak H, Dybała J 2010: Slaughter use of once-bred gilts as a method for profitable production of pork (in Polish). Rocz Nauk Zoot Monografie i Rozprawy 44: 103-111

Kapelanski W, Grajewska S 2005: Problems associated with slaughter utilization of first farrowing sows (in Polish). Zywnosc (Nauka, Technologia, Jakosc) 44 (Suppl): 65-77

Kapelanski W, Grajewska S, Bocian M, Kapelanska J 2007a: Slaughter indicators and carcass traits as related to changes in body weight during lactation and post-weaning period of primiparous sows. Anim Sci Pap Rep 25: 231-239

Kapelanski W, Grajewska S, Wajda S, Bocian M, Kapelanska J 2007b: Meat characteristics as related to changes in body weight during lactation and post-weaning period of primiparous sows. Anim Sci Pap Rep 25: 241-248

Kim SW, Easter RA 2001: Nutrient mobilization from body tissues as influenced by litter size in lactating sows. J Anim Sci 79: 2179-2186

Nutrient requirements of pigs. Nutritive value of feedstuffs (in Polish) 1993: The Kielanowski Institute of Animal Physiology and Nutrition (Editor). Jablonna, Poland

Pohja MS, Niinivaara FP 1957: Determination of meat water holding capacity with use of constant pressure (in German). Fleischwirtschaft 9: 193-196

Revell DK, Williams IH, Mullan BP, Ranford JL, Smits RJ 1998: Body composition at farrowing and nutrition during lactation affect the performance of primiparous sows: I. Voluntary feed intake, weight loss, and plasma metabolites. J Anim Sci 76: 1729-1737

StatSoft, Inc. 2008: STATISTICA (data analysis software system), version 8.0

Thaker MYC, Bilkei G 2005: Lactation weight loss influences subsequent reproductive performance of sows. Anim Reprod Sci 88: 309-318

Valros A, Rundgren M, Spinka M, Saloniemi H, Rydhmer L, Hulten F, Uvnas-Moberg K, Tomanek M, Krejci P, Algers B 2003: Metabolic state of the sow, nursing behaviour and milk production. Liv Product Sci 79: 155-167 